April 2011

\title{
Utopian Goals, Unasked Questions: Reflections on a Proposed Military Planning Handbook for Response to Mass Atrocities against Civilians
}

Roger W. Smith

Follow this and additional works at: https://digitalcommons.usf.edu/gsp

\section{Recommended Citation}

Smith, Roger W. (2011) "Utopian Goals, Unasked Questions: Reflections on a Proposed Military Planning Handbook for Response to Mass Atrocities against Civilians," Genocide Studies and Prevention: An International Journal: Vol. 6: Iss. 1: Article 11.

Available at: https://digitalcommons.usf.edu/gsp/vol6/iss1/11

This Articles is brought to you for free and open access by the Open Access Journals at Digital Commons @ University of South Florida. It has been accepted for inclusion in Genocide Studies and Prevention: An International Journal by an authorized editor of Digital Commons @ University of South Florida. For more information, please contact digitalcommons@usf.edu. 


\title{
Utopian Goals, Unasked Questions: Reflections on a Proposed Military Planning Handbook for Response to Mass Atrocities against Civilians
}

\author{
Roger W. Smith \\ Professor Emeritus, College of William and Mary
}

The proposed handbook, MARO: Mass Atrocity Response Operations; A Military Planning Handbook, offers many valuable suggestions about how the military can be prepared for intervention in situations of mass atrocity against civilians. The chief flaw of the document is that it places the military at the center and banishes the political, diplomatic, humanitarian, and reconstructive elements of intervention to the periphery of its focus. As a result, it sets up utopian goals for the military to rebuild devastated societies, fails to ask crucial questions about coordination and decision making in the political and military hierarchies, largely ignores international relations and their possible impact on intervention, creates structures that are excessively complicated, and by emphasizing structure (formal organization) it tends to ignore the vital element of process (the process by which decisions are made and implemented). The authors of the report view genocide and mass atrocity against civilians almost exclusively from the lens of the military. This approach is severely flawed for a variety of reasons, the main ones being that genocide and atrocity do not exist in a military vacuum and that many of the tasks that the handbook assigns to the military are beyond its competence.

The military focus is announced in the first paragraph of the report: lack of thinking about how to use the military to intervene in the face of mass atrocities against civilians has contributed significantly to the failure to act in the past. ${ }^{1}$ The problem has not been simply a failure of political will, but of military doctrine and planning with respect to humanitarian intervention. The handbook that is offered by the MARO Project "can help shift the policy debate from 'whether' to 'how' to intervene to stop widespread violence against civilians" (7). The authors' hope is that it can "catalyze," that is act as an agent to precipitate and speed up, action during mass atrocities (15).

Also in the opening pages, there are already some of the unasked questions that characterize the report. Is it the case that the failure to intervene has been the result of a lack of military doctrine, a calculation of national interest, or sheer indifference? Is the report's bias toward intervention shared by those in the military who would have to face what the report itself describes as an operation characterized by complexity, contingency, and a high potential for unanticipated consequences? Further, would the military leaders welcome the many tasks that the report assigns to them in the aftermath of the fighting, such as the tasks of nation-building and economical restoration, or view these as outside of the military's call of duty? And crucially, no criteria are provided to determine when intervention would be

Roger W. Smith, "Utopian Goals, Unasked Questions: Reflections on a Proposed Military Planning Handbook for Response to Mass Atrocities against Civilians," Genocide Studies and Prevention 6, 1 (April 2011): 77-80. (C) 2011 Genocide Studies and Prevention. doi:10.3138/ gsp.6.1.77 
warranted and the handbook does not offer any discussion of the various factors that must be considered before embarking on such a path: ethical and political issues, reactions from other countries, the probability of success, possible conflicts with other goals, and the duration of the intervention. None of these questions are intended as arguments against interventions, but they are questions that must be considered.

The unasked question that runs throughout the report is that of competence. The military is expected to gather enormous amounts of intelligence on every aspect of a MARO situation: political, economic, social, possible international reactions to intervention, and so forth. Do they have the competence to do so? And is it even the case that so much information must be collected and analyzed in order for a successful intervention to stop the atrocities? There appears to be a built-in tendency in the report to attempt to cover every possible base but to also leave important questions unasked. The result is a complexity that obscures what is vital to the success of the mission and the introduction of much that is irrelevant to the project at hand. Consider in this light what the authors have to say about the economic information that MARO planners must have:

The analysis should include key considerations with respect to agriculture, manufacturing, trade, gross domestic product, natural resources, income distribution, poverty, unemployment, corruption, black marketing, narcotics trafficking, human trafficking, and humanitarian assistance needs. (49)

Perhaps all of this information could be useful, and certainly information on humanitarian assistance needs is necessary, but the planners need to focus more on the mission at hand, distinguishing between information that is essential and that which is not. Even so, the question of who is competent to collect and analyze the information remains.

The report views the many issues of intervention mainly as an exercise in military preparedness and execution. It recognizes, however, that the matter of intervention is vastly complicated and that coordination with many groups must ensue. This theme surfaces from time to time in the handbook, but it is always on the periphery, and what is actually to be done about coordination is vague in most instances. At the same time, there is the re-appearance of the unnecessary complexity to which this report is prone even as it pushes everyone but the military to the sidelines.

The problem of intervention is obviously related to politics, domestic concerns, international relations, international organizations such as the United Nations, and NGOs (non-governmental organizations), as well as the military forces that might carry out the intervention. With regard to the latter, it can involve one country, several countries, or a broad array of forces; above all, it is a question of authorization, but such authorization has not generally been granted under international law. The humanitarian gunslingers (who have not been disinterested, shall we say) have pretty much had their way. India went into East Pakistan in 1971 without authorization, but stopped the slaughter in what is now known as Bangladesh; the Vietnamese invaded Cambodia and brought an end to the Khmer Rouge killing of its own people; the United States intervened in Kosovo with NATO's authorization but without the support of the UN Security Council.

The authors of the report recognize the need for coordination and the many problems associated with it (and they focus on the US military and political institutions rather than take a broad look at complicating factors, such as the fact that other 
countries exist and have interests and points of view as well). But their response is to sponsor a structural solution and, in so doing, to increase the complexity that stands in the way of both an understanding of the issues and action where it is required. The kind of coordination they describe is absolutely impossible: bureaucrats from a multitude of agencies, and perhaps also those from other countries and international organizations, would be bumping into each other. Because this particular statement about the parties that would be involved extends for about two pages, I will only cite a portion of it, but it can speak, as it were, for itself:

Currently within the US government, the Department of State Office of the Coordinator for Reconstruction and Stabilization (S/CRS) is the primary point of contact for interagency ("whole of government') training, assessments, plans, and associated planning processes that pertain to MARO. S/CRS coordinates with other agencies, particularly other offices in the Department of State, USAID, and the National Security Council (NSC), which chairs Interagency Policy Committees (IPCs) that are responsible for coordinating national security policy. During a crisis, the Interagency Management System (IMS) may be activated including the formation of a Country Reconstruction and Stabilization Group (CRSG) which is chaired by the appropriate Regional Assistant Secretary of State, the S/CRS Co-ordinator, and the appropriate NSC Senior Director. Other IMS structures include the Integration Planning Cell (IPC), the Advance Civilian Team (ACT), and, potentially, Field Advance Civilian Teams (FACTs). For any government effort, joint military training, exercises, and similar types of habitual engagement among civilian and military actors help to build common operating assumptions and procedural familiarity. (84-85)

This line of thought continues for another page and brings in even more groups and the need for coordination, but the point, I think, has been made. The approach of the MARO Project is bureaucratic, structural, and impossibly complicated. It also utterly ignores process in favor of structure. Further, there are surely divisions within the ranks of some groups or governmental units within the many groups that are mentioned and there may also be conflicts between the many different units and organizations that the quotation outlines. The question is not just what structures there are, though this is important, but about the process within and between such organizations. It is this question that is totally ignored by the MARO report.

There are unasked questions as well as utopian expectations in the report, despite the fact that it provides some notes of caution. The report is realistic in recognizing that difficulties could occur on the ground during intervention, that there could be shifting forces within the group(s) of perpetrators, and that neighboring countries could aid and abet those engaged in the killings. It does not, however, address how the home country would perceive mounting casualties or whether it would even understand the reasons for the intervention. And if the duration of the intervention-whether conducted by the United States, on which the report focuses, or another nation-extended would support for the intervention decline significantly? If so, what impact would the loss of that support have on the existing intervention and/or on future interventions?

Having recognized the dangers of intervention, MARO's author-group, from Harvard and the US Army, goes on to create all kinds of utopian expectations and make excessive demands on the US military, which would be involved in humanitarian interventions to stop the slaughter of civilians wherever they might occur. In this 2010 report there is no mention that the United States is already involved in two wars.

The US military is capable of conducting a military intervention to prevent mass deaths of civilians at the hands of their own government or of other perpetrators. 
But the question that always arises is "what about the aftermath?"; what will happen after the killing ends? It is here that MARO becomes utopian in the extreme, reaching not only far beyond the military's capability to repair the scourge of genocide, but really reaching beyond anyone's capability to do so. The deaths, devastation of the landscape and of cultural monuments, the destruction of the economy and of the justice system, and the need to reconstruct the society and the state to prevent such atrocities in the future are quite complex issues.

$M A R O$ sets up very expansive goals, and just how they are to be met is unclear. The handbook places huge burdens on the military to carry them out in ways that the military has little experience of doing. Of course, there are also calls for working with civilian groups; nevertheless, the initial requirement is that a transitional military force will be the governing authority. The document discusses the many complications that can arise at this point and the responsibilities that will be involved in confronting them. Another issue that arises has to do with the duration of the operation: Is this a short-term commitment or will it perhaps continue for years?

MARO demands a utopia from the American military, forgetting that Washington is and always has been reluctant to intervene to stop genocide. The demands made in the report indicate a misplaced allocation of responsibility onto the military and assign untenable responsibilities to it in the aftermath of genocide. Further, the expectations that are made of the military do not constitute the only issue present in the report. For the scope of the present commentary, I will consider only one example of such demands, but it is indicative of the tenor of the whole report:

Governance and Rule of Law.

Support establishment of effective institutions and laws, and the rule of law.

Identify and apprehend perpetrators.

Locate and safeguard witnesses, documents, and other evidence.

Support peaceful redress of grievances.

Monitor vulnerable groups and prevent human rights abuses; implement effective warning mechanisms.

Protect key political and societal leaders.

Establish Transitional Military Government, if needed.

Transition authority to others, as appropriate.

Support legitimate and effective governance.

Dissuade corruption. (107)

In the end, I think that the MARO group has done a service to us all, but much of it constitutes in warning us about the simplistic, bureaucratic, and structural thinking that went into the report. My feeling is that, having produced the report from the perspective of the military, they now need to re-produce it from the perspectives of genocide scholars, foreign scholars, and even from the Washington establishment, which, I think, will not like this report.

\section{Note}

1 Sarah Sewall, Dwight Raymond, and Sally Chin, MARO: Mass Atrocity Response Operations; A Military Planning Handbook (Cambridge, MA: Harvard Kennedy School / Carr Centre for Human Rights Policy, 2010), 7. Subsequent references appear parenthetically in the text. 